\title{
Ukrainian Constitutional Court: Attacks and Backlash
}

Author(s): Samuel Fonteles

Source: Kyiv-Mohyla Law and Politics Journal 7 (2021): 27-50

Published by: National University of Kyiv-Mohyla Academy

http://kmlpj.ukma.edu.ua/ 


\title{
Ukrainian Constitutional Court: Attacks and Backlash
}

\author{
Samuel Fonteles \\ PhD candidate \\ Federal University of Paraná (UFPR), Brazil
}

\begin{abstract}
This article intends to analyze Ukraine's Constitutional Court in the light of the tolerance interval theory and the backlash thesis, through a case study, which is, the decision issued on October 27, 2020, that held unconstitutional part of the powers of the National Agency for the Corruption Prevention (NAPC). Three comorbidities particular conditions that weaken the court and render it vulnerable to attacks - in the Ukrainian system are presented: Ukrainian democracy, autocracies tendencies in the presidency, and lack of public confidence in the judicial system. Through the adoption of a Comparative Constitutional Law approach, an index measuring the impact of the ruling is developed and calculated, allowing a comparison of the consequences to other notable controversial rulings in the world. After discussing the findings, the article concludes with some reflections and predictions on the longevity of the Ukrainian Constitutional Court.
\end{abstract}

Key Words: backlash, tolerance intervals, attacks, Constitutional Court, Ukraine.

\section{讨}

\section{Introduction}

As opposed to what common sense might suggest, constitutional courts are as vulnerable as crystals. Depending on the position adopted in a judicial decision, there are at least two sources of attacks against them: The other branches of the government and the people themselves.

From a horizontal point of view, courts are frequently challenging the preferred position of the political actors, that is, the Parliament and the President. Every actor has its preferences when it comes to themes such as separation of powers, fundamental rights, the presidential system, and much else.

Assuming a strategic behavior from judges, executives, and legislators, these actors will evaluate the costs and benefits of reacting to one another. So, there is a tolerance interval within which it would be safe for constitutional courts to render rulings against the aforementioned preferred positions. ${ }^{1}$ Beyond these boundaries, distress between institutions becomes more likely to take place.

1 Lee Epstein, Jack Knight, and Olga Shvetsova, "The Role of Constitutional Courts in the Establishment and Maintenance of Democratic Systems of Government," Law \& Society Review 35 , no. 1 (2001). 
On the other hand, from a vertical perspective, tribunals are often dealing with the will of the people, sometimes going against it. By exercising the judicial review, to some extent, courts are almost ever running the risk of sparking a social rage due to its counter-majoritarian role. Then, when judges ignore the limits of constitutional adjudication, a strong backlash reaction is triggered by the ruling. ${ }^{2}$

Finally, sometimes, both phenomena occur at the same time. In 2O2O, the Malian Constitutional Court overturned the provisional results for parliamentary elections. Subsequently, Ibrahim Boubacar Keïta, President of Mali, repealed the licenses of the Justices, announcing the dissolution of the Malian Constitutional Court. The people caused treacherous civil unrest by protesting in the streets, leaving four people dead and resulting in the arrest of leaders of the opposition.

The court's behavior crossed the line of tolerance interval, as well as triggered a fierce backlash. In other words, both the sources of attacks, in a horizontal and vertical perspective, were actioned by the decision rendered by the Malian Constitutional Court. Maybe, the effect (the dissolving of the court) was greater than the sum of the individual perspectives when individually considered (synergistic effect).

This article intends to analyze Ukraine's Constitutional Court in the light of the "tolerance interval theory" ${ }^{3}$ and the backlash thesis. ${ }^{4}$ The work comprises four parts. The first one offers an overview of the theoretical framework on attacks against constitutional courts. The second section provides a concrete case study, that is, the decision of Ukraine's Constitutional Court rendered on October 27, 2020. Still in this session, three comorbidities - the presence of particular conditions that weaken the court and render it vulnerable to the attacks - are introduced. In the third section, an index measuring the impact of the ruling is developed and calculated, allowing a comparison of the consequences to other notable controversial rulings in the world. After discussing the findings, regarding the risk assumed by the Constitutional Court, the article resolves with some reflections on its longevity.

\section{The horizontal perspective: tolerance interval theory}

Courts are not islands. In a rule of law, there are interactions between institutions and the government. Approximately twenty years ago, an interesting model was developed to explain the courts' role in the establishment and maintenance of constitutional democracy.

There were two competing positions on this subject. The first argued that courts were unconstrained actors, in the sense that they did not need to worry about the government preferences. In short, tribunals were autonomous to set their own policies, regardless of the likely reaction from the other branches of the government.

2 Gerald Rosenberg, The Hollow Hope. Can Courts Bring About Social Change? (Chicago: The

University of Chicago Press, 2008).

3 Epstein, Knight and Shvetsova, The Role of Constitutional Courts.

4 Rosenberg, The Hollow Hope. 
Contrastively, another view claimed that courts were constrained actors because they should take into account the preferences and likely actions of executives and legislators. ${ }^{5}$ For the purpose of this article, the first conception is not substantive. The latter is adopted as a premise, mainly due to pragmatic reasons and empirical evidence acclamatory of the conception that, depending on certain variables, courts are vulnerable before the other political actors. Indeed, if the goal of the courts is longevity, they may take into consideration the veto players, ${ }^{6}$ policies, and even public opinion.

Lee Epstein, Olga Shvetsova, and Jack Knight studied the interactions among political actors, concluding that, in emerging democracies-especially in Eastern Europe, - courts must be attentive to the preferences of external actors if they wish to advance their goals. ${ }^{7}$ Ignoring these aspects could lead a court to suffer many attacks, depending on the drawbacks and benefits to do that.

In 1999, Hugo Chávez dissolved the Venezuelan Supreme Court. Few years before that, in 1993, Boris Yeltsin's decree had suspended the activities of the Russian Constitutional Court. Additionally, this was the same year when $3 / 7$ of Justices from the Peruvian Constitutional Courts were impeached after having tried to prevent the third tenure of President Fujimori. In 2O2O, Volodymyr Zelenskyy issued a decree suspending the Chief Justice of the Ukrainian Constitutional Court.

A significant distance in space and time, but a similar phenomenon in all examples provided. These cases represent the hypothesis of exogenous conflicts, that is, conflicts established by actors from different origins or distinct branches of government.

Sometimes, however, the behavior of the courts is also capable of attracting an endogenous conflict. In Guatemala, a controversial commission, supposedly involved in corruption schemes, nominates the judges that would serve in the Supreme Court and Appellate Courts. This was precisely the reason why the Constitutional Court, in an effort to eradicate appointments of dubious authorities, suspended the ongoing selection process. The aftermath was a range of attacks to the Constitutional Court, perpetrated by the Supreme Court - as well as the Congress and even the Prosecutor's Office. The crisis was described by the United Nations Special Rapporteur on the independence of judges and lawyers. ${ }^{8}$ It is true the affirmation that the Constitutional Court of Guatemala crossed the line, reaching matters outside the tolerance interval.

While courts preserve democracy, democracies preserve courts. It can be considered a feedback loop. Courts are gatekeepers of democracy, but a democratic

\footnotetext{
$5 \quad$ Epstein, Knight and Shvetsova, The Role of Constitutional Courts, 125.

6 George Tsebelis, Veto Players. How Political Institutions Work (New Jersey: Princeton University Press, 2002), 19.

$7 \quad$ Epstein, Knight and Shvetsova, The Role of Constitutional Courts, 125.

8 Diego García-Sayán, "Guatemala: Attacks against Constitutional Court and Delays in the Appointment of Judges to High Courts must Stop, United Nations Human Rights Officer of the High Commissioner, November 19, 2020, Accessed December 25, 2021, https://www.ohchr.org/ en/NewsEvents/Pages/DisplayNews.aspx? NewsID=26521\&LangID=E.
} 
regime is a natural habitat that provides the conditions for the maintenance of tribunals. The stronger and more stable a democracy is, the safer a Constitutional Court is. In an ambiance of authoritarianism or democratic backsliding, going beyond the limits of tolerance is a treacherous attitude.

\section{The Vertical Perspective: Backlash}

Courts develop several doctrines in order to avert controversial issues. These partially reflect the perception that frequent judicial intervention in the political process allows such political reaction that the "court would be destroyed." 9 Referring to the Supreme Court of the United States, Kurland pointed out that

"its essentially anti-democratic character keeps it constantly in jeopardy of destruction." 10

The History reveals a possible and likely etiological link between judicial positions in controversial issues and an enraged rematch from the group whose interests were affected by the decision. It is as if there were a political invisible trigger, which is triggered whenever Courts rush into moral disagreements, not yet matured by society. Accordingly, when a decision inflames social resentments, it has been common to talk about backlash."1

The highest the level of distrust in judges and courts, the stronger the backlash reaction to a controversial ruling. The distrust, in turn, is not always linked with corruption. Sometimes, the disproportionate difference between the incomes of judges and citizens is a relevant aspect to increase the risk of a backlash. Such as the Jacobin spirit from the French Revolution, the rage arises among the people. The implications of this statement are far from trivial, mainly in the further analyses of the Ukrainian case.

The backlash is subjected to a mechanistic understanding. Arguing almost the existence of a logical implication (if A, then B), Cass Sunstein points that:

"If the Court rules in a certain way in such cases, public outrage could significantly affect national politics and undermine the very cause that the ruling is attempting to promote." ${ }^{12}$

Philip B. Kurland, “Toward a P. Supreme Court," University of Chicago Law Review 37, no. 1 (Fall 1969): 20.

11 Samuel Fonteles, Direito e Blacklash (Salvador: Jurispodivm, 2019), 23.

12 Cass Sunstein, "Backlash's Travels", University of Chicago Public Law \& Legal Theory 157 (March 2007): 1 
Similarly, Richard Posner arose an interesting cause and effect relationship:

"Did Warren Court's decision of expanding the constitutional rights of criminal defendants contribute to an increased crime rate in the 196 os and 1970s and provoke a legislative backlash, increasing the severity of sentences?" 13

Referring to the backlash phenomenon, Michael Klarman explains:

"Court decisions on highly charged issues that produce massive resistance to the ruling, arguably set back the cause that the decision seems to advance, at least in the short term, and possibly have larger, often unpredictable effects on politics as well." ${ }^{14}$

Indeed, it makes sense to understand the phenomenon in a mechanistic way.

The backlash is a social fact. It is also, for the same reason, a type of social coercion. According to Durkheim, a social fact is recognized by its "external coercive power" exercised over the individuals..$^{15}$ The presence of this power is identified, for example, through the "resistance that the fact opposes to any individual effort that aims to violate it." ${ }^{16}$ This is precisely the mechanism involving judges and courts, that is, the strong social resistance opposed to judicial rulings (backlash) characterizes a social fact and, therefore, a type of social coercion over the tribunal and its decisions.

Appreciated as a social fact, the national backlash can be exteriorized in several ways. Without the pretension to list all of them, it is important to mention the most probable ways by which this phenomenon manifests itself. These patterns were found by analyzing 8 prototypical cases, ${ }^{17}$ from which I identified 10 (ten) common features in the backlash reaction against courts. ${ }^{18}$ In the words of Ran Hirschl, "

a prototypical case serves as a representative exemplar of other cases exhibiting similar pertinent characteristics." ${ }^{19}$

Richard A. Posner, “Against Constitutional Theory”, New York University Law Review 73, no. 1 (April 1998): 12.

Michael Klarman, “Courts, Social Change and Political Backlash” (Speaker's notes, Washington, DC, March 31, 2011), Georgetown University, https://scholarship.law.georgetown.edu/cgi/ viewcontent.cgi?article $=1001 \&$ context=hartlecture Émile Durkheim, As Regras do Método Sociológico (São Paulo: Edipro, 2012): 38.

16 Durkheim, As Regras do Método Sociológico, 38.

17 Ran Hirschl "On the Blurred Methodological Matrix of Comparative Constitutional Law”, The Migration of Constitutional Ideas, ed. by Sujit Choudhry (Cambridge: Cambridge University Press, 2007): 53 .

18 Fonteles, Direito e Backlash, 74.

19 Hirschl, On the blurred methodological Matrix of Comparative Constitutional Law, 53. 
The selection of the cases took into account their relevance for the Comparative Constitutional Law, as well as the concrete difficulties in compliance with the decisions, precisely due to the social coercion exercised over them. For this reason, they must be considered as prototypical cases. The archetypal characteristics of backlash, such as extracted from these cases, are listed below: ${ }^{20}$

\section{Characteristics of Backlash}

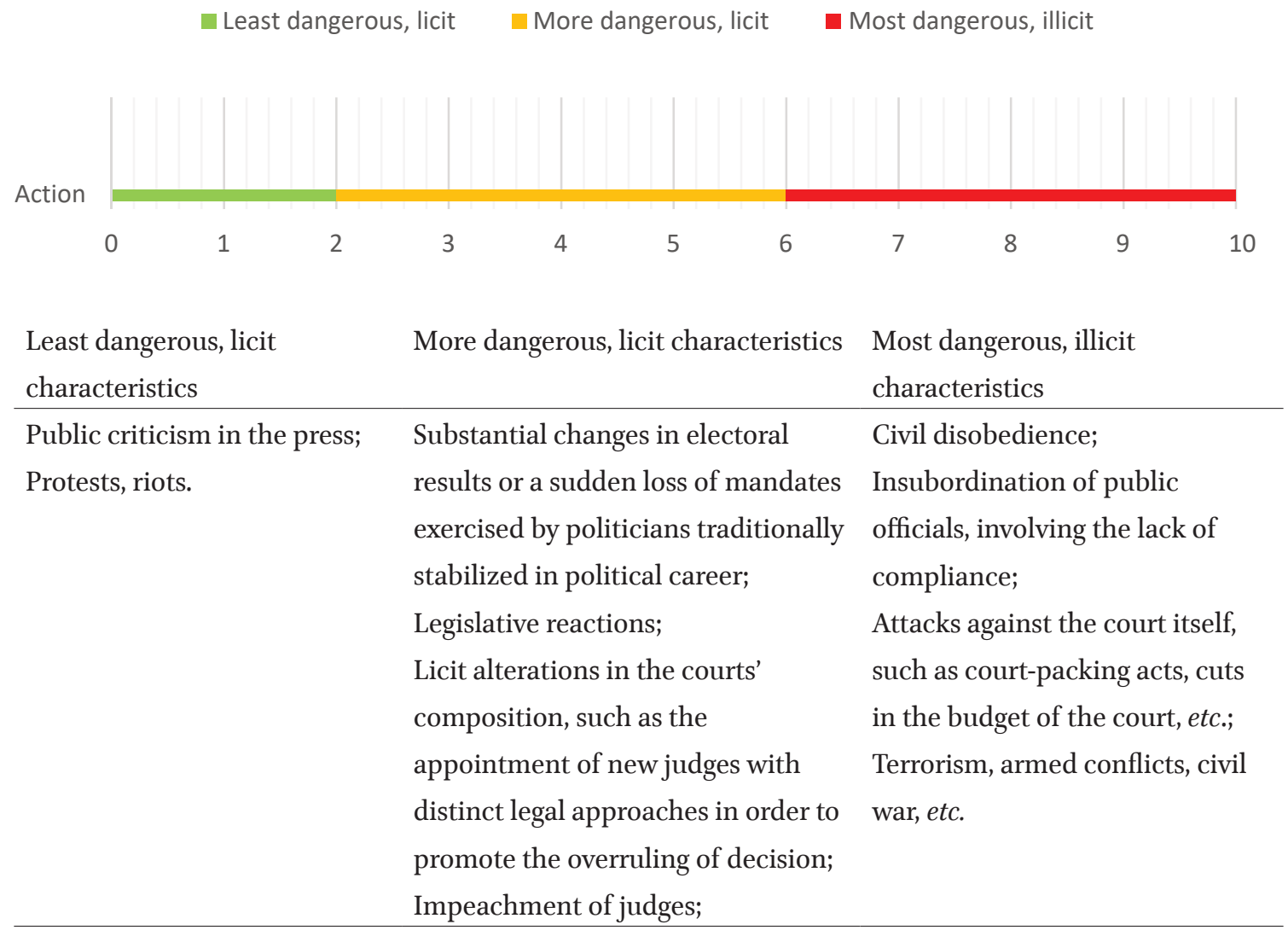

Illustration 1: Characteristics of backlash. Source: author's elaboration (2021)

The list is not exhaustive, but these are, for sure, the primary ways by which a backlash against a judicial ruling will express itself as a social fact. Interestingly, the Constitutional Court of Ukraine is facing a backlash that met many of these examples.

In theory, the backlash starts with public criticisms, street protests and goes through all aforementioned steps, reaching the last one (armed conflicts). For didactic purposes, it is possible to think in a chronological line with well-defined stages. However, in a more aggressive version of backlash, sometimes this path is shortened due to a rapid escalation in social reaction. This is particularly the case of Ukraine in Euromaidan, for instance, when protests suddenly became armed conflicts, culminating in the deposition of Viktor Yanukovytch. ${ }^{21}$ The conflicts were more violent than those in Spain,

20 Fonteles, Direito e Backlash, 74.

21 Fonteles, Direito e Backlash, 79. 
in 2010, after the Spanish Constitutional Court had refused to recognize Catalonia as a nation. Historically, Ukraine has precedents of gaps between protests and armed conflicts.

\section{A Case study: Ukrainian Constitutional Court as an Obstacle to the Ideals Embodied by the Euromaidan}

Ukraine is not a monolithic stone. It is a country with ethnic diversity, where Russia and Europe are, to a certain extent, exerting their influence over the people, that is, both dispute the Ukrainian citizens. The reason is, among others, the geographical position.

After the Government's decision of suspending the signing of an association agreement with the European Union, in 2013, the Euromaidan arose as a strong reaction and was inflamed due to the perception of corruption. ${ }^{22}$ The Revolution of Dignity (2014) left a deep sense of aversion to corruption, as well as an irreversible desire for integration towards the European Union.

It would not be an exaggeration to affirm that, in the collective imaginary, the Ukrainian Constitutional Court has been perceived as an obstacle to the achievement of these goals. In the words of Andrii Nekoliak,

"the pro-Russian political camp has been utilizing constitutional adjudication to crack down on post-Euromaidan achievements." ${ }^{23}$

This is certainly the worst stereotype for the tribunal. Once this image is consolidated, any ruling rendered by the court becomes suspicious.

In 2020, on October 27, the Ukrainian Constitutional Court held unconstitutional certain provisions of the Law of Ukraine "On Prevention of Corruption" concerning the powers of the National Agency for the Corruption Prevention (NACP) to verify the accuracy of financial declarations of public officials, and Article 366-1 of the Ukrainian Criminal Code, which provides for criminal liability for submitting false declarations and failure to submit a declaration by public officials (No.13-r/202O). The court assumed a breach of the judicial independence enshrined by the separation of powers, which was, therefore, a violation of the Rule of Law principle.

The mandatory public asset declarations by officials are an important measure of transparency and accountability, but the penalties associated with lying in these

22 By coincidence, Brazil also experienced, in the same year (2013), a type of "Brazilian

Euromaidan." Due to a general perception of corruption, thousands of citizens seized the streets in a movement known as the June Demonstration. The results were interesting, but analyzing them is beyond the scope of this article.

23 Andrii Nekoliak, "A Damaged Court Causing a Constitutional Crisis: The Decision of Ukraine's Constitutional Court on the Anti-Corruption Reform," VerfBlog, December 5, 2020, accessed December 25, 2021, https://verfassungsblog.de/a-damaged-court-causing-aconstitutionalcrisis/. 
declarations ceased to be valid. Consequently, the court struck down part of the powers of the National Agency for the Corruption Prevention (NAPC), declaring it unconstitutional (No. 13-r/2O2O).

Before this decision, on another occasion, the tribunal also had held that the Head of the National Anti-corruption Bureau (NABU) had been illegally appointed by the President (No. 9-r/2O2O). In the court's view, the list of the President's power established by the Constitution, in particular concerning the appointment of officials, is exhaustive. ${ }^{24}$ In 2019, in turn, the court ruled that the enrichment provision in Article 368 of the Criminal Code of Ukraine is not in conformity with the Ukrainian Constitution, more specifically the presumption of innocence (No. 1-r/2019).

To sum up, the Constitutional Court held the establishment of the anti-corruption institutions as against the Constitution of Ukraine. In a clear relation of cause and effect regarding the court's ruling on October 27, the President of Ukraine, Volodymyr Zelenskyy, issued a decree suspending the Chief Justice, Oleksandr Tupytsky, for 2 (two) months. The suspension is not allowed by the Constitution, according to which dismissal of a judge of the Constitutional Court of Ukraine from his office is decided by not less than two-thirds of its constitutional composition (Article 149-1). Despite the constitutional text, the Court didn't react.

In addition, Zelenskyy declared that he intended to reform the tribunal. To some extent, despite the deep differences between both ambiances, the initiative reminds the "court-packing plan" announced by Franklin Delano Roosevelt, in order to obtain favorable rulings on New Deal legislation.

The ruling issued on October 27 was a clear obstacle to Ukraine's process of European integration and represented a high economic cost for the country. Without the asset declaration system, the International Monetary Fund will not concede loans to Ukraine, which is especially concerning during the pandemic (SARS CoV-2/COVID-19). Transparency and accountability against corruption were Ukraine's commitment to the IMF. Finally, the ruling hindered the visa-free travel agreement in the European Union. So, pragmatically, the judicial decision threatened the political and economical integration with Europe.

The conflict between President Zelenskyy and the Constitutional Court seems to evoke the tension between two values: On the one hand, the rule of law; on the other hand, an efficient struggle against corruption. This is, however, a false dichotomy. Ideally, the values are not mutually exclusive. ${ }^{25}$

24 For a comprehensive and deep understanding of the Constitutional Court's politics in Ukraine, including these two controversial cases (No. 9-r/2O2O and No. 13-r/2O2O), see: Oleksandr Marusiak, "Ukraine," The I.CONnect-Clough Center 2020 Global Review of Constitutional Law (March 2021): 320-323, accessed December 25, 2021, https://papers.ssrn.com/sol3/papers. cfm?abstract_id=3800451. 


\subsection{Comorbidities}

When it comes to analyzing the tolerance interval theory and backlash thesis in the specific case of Ukraine, there are at least three comorbidities: (i) Ukrainian Democracy; (ii) the persistent problem of presidential autocracy, and (iii) the popular distrust in the judicial system. While the latter elevates the chance of a backlash, the others restrict the tolerance interval. All these variables, in their own ways, increase the risk of attacks against the Constitutional Court. ${ }^{26}$

\subsubsection{Ukrainian Democracy}

Scholars claim that the third wave of democratization began with the displacement of Latin American dictatorships in the 1970s and continued through the breakdown of the Soviet Union. ${ }^{27}$ The road to reach a full democracy, however, is still being pursued.

If the democracy was black and the lack of it was white, some countries in Eastern Europe, during a certain period or even on the current days, would be considered gray. This metaphor explains that, according to Freedom House Organization, the current status of Ukraine is considered as a "transitional or hybrid regime." The democracy percentage is 39.88 and the Democracy score is 3.39 . The literature has claimed that Ukraine is experiencing a "democratic backsliding." ${ }^{8}$

The rebirth of the Ukrainian Democracy occurred in 1991 when the country became an independent state. Before this mark, it was the totalitarian period of the Soviet Union. The Constitutional Court, in turn, was established in 1996. A recent Democracy and a recent tribunal, form exactly the context where constitutional courts are constrained by the other political actors and, therefore, the tolerance interval may be noted. ${ }^{29}$

President of Ukraine vs the Constitutional Court," VerfBlog, January 2021, accessed December 25, 2021, https://verfassungsblog.de/false-dilemma/.

The metaphor of comorbidity was used by Tom Ginsburg and Mila Versteeg (2020:6-7), in a different - but somehow similar — context. Describing that political systems that were already vulnerable to repression are those that have seen the most authoritarian responses during the pandemic, the authors said: "To analogize to the human body, one might consider these countries to have 'comorbidities', the presence of other conditions that weaken the host and render it vulnerable to the virus" (Ginsburg and Vertseeg, 2020:7). Here, instead of the virus of authoritarianism, we are dealing with attacks against the court.

Mark Tushnet, Advanced Introduction to Comparative Constitutional Law (Northampton: Edward Elgar, 2014): 1. Steven Levitsky and Daniel Ziblatt, How democracies die. What history reveals about our future (Harlow: Penguin Book, 2018): 5 . 


\subsubsection{Autocratic Tendencies in Executive}

The second comorbidity is the autocratic tendency in the presidency. ${ }^{30}$ The literature demonstrates that, during the post-Soviet era, Ukrainian Presidents have attempted to expand their powers beyond the constraints of the Constitution, sometimes by manipulating the Constitutional Court to shift the institutional balance in favor of themselves. ${ }^{31}$

The pattern has been an intrinsic feature of the presidents' behavior through Ukrainian history. As stressed by Choudhry, Sedelius \& Kyrychenko,

"Competition for control of the courts has been an essential part of the power grabs among the key political actors during the post-Soviet era. For example, in the presidential election campaign of 2010, Prime Minister (and presidential contender) Tymoshenko controlled the Supreme Court; her main opponent, Yanukovych, controlled the Supreme Administrative Court; and President Yushchenko controlled the Constitutional Court." 32

In this dangerous scenario, in order to avoid attacks, the Constitutional Court would need the support of a relevant ally like the Verkhovna Rada. But, before going against the ideal points of the President, the bench had also already contradicted the ideal points of the Legislative branch. A few years before, the Constitutional Court had held constitutional the draft law on the abolishment of parliamentary immunities, emphasizing that they are not fundamental rights (No. 1-v/2018, No. 2-v/2018). The bench was criticized for the position adopted ${ }^{33}$ and, certainly, the decision was only the first step towards a long dialogue between institutions. ${ }^{34}$ The Parliament will probably

30 Sujit Choudhry, Thomas Sedelius and Julia Kyrychenko, Semi-presidentialism and Inclusive Governance in Ukraine. Reflections for Constitutional Reform (Stockholm: International Institute for Democracy and Electoral Assistance, 2018): 17.

31 Choudhry, Sedelius and Kyrychenko, Semi-presidentialism and Inclusive Governance in Ukraine. Reflections for Constitutional Reform, 17-18.

32 Hale, "Formal Constitutions in Informal Politics," quoted in Choudhry, Sedelius and Kyrychenko, Semi-presidentialism and Inclusive Governance in Ukraine. Reflections for Constitutional Reform, 17; Choudhry, Sedelius and Kyrychenko, Semi-presidentialism and Inclusive Governance in Ukraine. Reflections for Constitutional Reform, 37.

Alina Cherviatsova, "Ukraine”, The I.CONnect-Clough Center 2018 Global Review of Constitutional Law (October 2018): 319-324, accessed December 25, 2021, https://papers.ssrn.com/sol3/papers. cfm?abstract_id=3471638. In Brazil, the Supreme Court (STF) did the same. Year after year, the STF has systematically suppressed the parliamentary immunities enshrined by the Constitution, on the grounds that constitutional rights are not absolute. Strategically, this has been costly for the tribunal. Many proposals for constitutional amendments and requests for impeachment against judges were 
evaluate the costs and benefits to react against the court, which, in its turn, can react to the reaction.

On the other hand, immediately after having challenged legislatures, the court needed their power as veto players to block the bills drafted by Zelenskyy and lawmakers after the ruling issued on October 27 (No.13-r/2O2O). Regardless of the sort of these bills, in any case, the Court assumed the risk of losing an important ally in a crucial moment. In other words, it deliberately put itself in a vulnerable condition.

Packing a court in any country is always concerning, but doing so in Ukraine is even more dramatic. The reason is Article 111 of the Ukrainian Constitution, according to which the decision of removing the President of Ukraine through an impeachment process is adopted by the Verkhovna Rada by no less than three-quarters of its constitutional composition, after the review of the case by the Constitutional Court of Ukraine.

Scholars have argued that

"the president must not be able to control or determine the composition of the institution that decides whether or not to impeach or remove the president - the Constitutional Court." 35 Furthermore, "a weak constitutional court has been considered as one of the main challenges to grant stability in Ukraine." 36

\subsubsection{The Lack of Public Confidence in the Ukrainian Judicial System}

The third comorbidity is the high level of public distrust in the Ukrainian judicial system. According to a Freedom House report regarding judicial framework and independence, "currently, citizens have little trust in the judicial system, viewing it as corrupt and politicized." ${ }^{37}$ Corruption is mentioned by Ukrainian scholars as a characteristic of many Ukrainian courts. ${ }^{38} \mathrm{~A}$ research conducted by the Razumkov Center's sociological service together with the Ilko Kucheriv "Democratic Initiatives"

filed in the National Congress. Depending on some variables, Parliament may not act as a veto player.

35 Choudhry, Sedelius and Kyrychenko, Semi-presidentialism and Inclusive Governance in Ukraine. Reflections for Constitutional Reform, 13.

36 Choudhry, Sedelius and Kyrychenko, Semi-presidentialism and Inclusive Governance in Ukraine. Reflections for Constitutional Reform, 18.

37 Yulia Yesmukhanova, "Score changes in 2020," Freedom House, 2020, accessed December 25, 2021, https://freedomhouse.org/country/ukraine/nations-transit/2O2O.

38 Ievgen Zveriev, "Interpretation Theories in Ukrainian Courts_Past and Present," Acta Juridica Hungarica 56, no. 1 (March 2015): 164. 
Foundation demonstrates that $77.5 \%$ of Ukrainians expressed distrust in the Judiciary as a whole. ${ }^{39}$

The Corruption Perception Index by Transparency International indicates that Ukraine occupies the $117^{\text {th }}$ position in the global rank, among 180 countries. On the scale of scores, Ukraine has 33 points out of 100, being o the extreme, considered as "highly corrupt" and 100 as "very clean". ${ }^{40}$ Comparatively, Mali-a country where the President repealed the licenses of the Justices, announcing the dissolution of the Malian Constitutional Court - occupies the $129^{\text {th }}$ position, performing a score of 30 (three points of difference between them).

This data is especially concerning when one considers that the Ukrainian Constitutional Court has carried the stereotype of a pro-Russian tribunal, with judges receiving a salary of around $\$ 7,500$, which represents twenty times the country's average ${ }^{41}$ a perfect context to host the Jacobin spirit.

\section{Calculating a Backlash Impact Index}

Like the Richter scale measures the magnitude of earthquakes, it is possible to calculate a backlash impact index for each ruling decided by a Constitutional Court. Knowing that the social reaction can be manifested with greater or lower strength, the proposed tool works as an intensity meter.

Measuring the impact of a ruling has the utility to enable fruitful comparisons between social reactions from different countries, in different moments of history. It is undeniable that many backlashes do not reach, for example, the reactive level aroused by Roe v. Wade (1973), when the Supreme Court of the United States legalized abortion.

The calculation is based on 10 (ten) externalizations examined in the previous topic. Every externalization originates a question, with an answer ranging in three

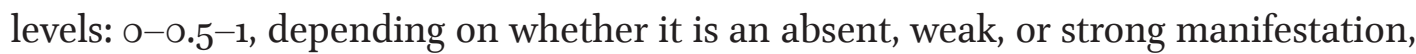
respectively. The score o represents the lowest degree of impact, while 1 means the greatest one. o.5, therefore, is an intermediate level. In other words, every question varies depending on the intensity by which the externalization occurred.

For example, if there was no legislative reaction, o is assigned. If it occurred in a weak form - 0.5. When strong - 1 . This methodology allows more accuracy in the questions because there is no way to calibrate the answers to the point of giving

39 “The Beginning of a New Political Year: Trust in Social Institutions," Razumkov Centre, July, 2020, accessed December 25, 2021, https://razumkov.org.ua/napriamky/sotsiologichni-doslidzhennia/pochatok-novogo-politychnogo-roku-dovira-do-sotsialnykh-instytutivlypen-2020r.

"Corruption Perception Index," Transparency International, 2020, accessed December 25, 2021, https://www.transparency.org/en/countries/ukraine.

41 Oleksiy Sorokin, “Constitutional Court Judges Live Far Beyond their Stated Means”, KYIV Post, November 6, 2020, accessed December 25, 2021, https://www.kyivpost.com/ukraine-politics/ constitutional-court-judges-live-far-beyond-their-stated-means.html. 
them a millimetric precision to measure social reactions. It is safer to deal with a scale composed of extreme and well-defined milestones: absent, weak, or strong reaction.

Accordingly, the burden of argumentation is often not located in whether the reaction occurred - a relatively easy task, - but instead to what extent it occurred. The reasoning is routinely why the reaction should be considered as strong or weak, which demands careful research of the facts.

Then, once calculated the individual value of each question, the next step is to provide the arithmetic mean.

Where:

$$
\text { (i) }=\Sigma x / n
$$

- (i) is the backlash impact index;

- $\mathrm{x}$ is the value of each question;

- $\mathrm{n}$ is the number of variables used.

$$
\operatorname{Impact}(\mathrm{i})=\frac{\mathrm{a}+\mathrm{b}+\mathrm{c}+\mathrm{d}+\mathrm{e}+\mathrm{f}+\mathrm{g}+\mathrm{h}+\mathrm{i}+\mathrm{j}}{10}
$$

The result will be a variation from o to 1 . On an ascending scale, the higher the value found for the index, the greater the impact or the strength of the backlash:

$\begin{array}{llllllllll}0 & 0,1 & 0,2 & 0,3 & 0,4 & 0,5 & 0,6 & 0,7 & 0,8 & 0,9\end{array}$

Illustration 2: Value of index in a scale. Source: author's elaboration (2021)

Finally, the index must be interpreted according to the intervals described in the following table:

Table 1: Value of index and the status of backlash.

Source: author's elaboration (2021)

\begin{tabular}{ll} 
INTERVAL (VALUE OF INDEX) & STATUS OF BACKLASH \\
\hline 0.1 a 0.3 & Weak impact \\
\hline 0.35 a 0.6 & Intermediate impact \\
\hline 0.65 a 1.0 & High impact \\
\hline
\end{tabular}

There are many advantages in working with indexes, even in Comparative Constitutional Law. Indexes aggregate a high quantity of data, synthesizing them in 
a numeric expression. They also allow communication between scholars, fostering an exchange of information.

It is worth pointing that the backlash phenomenon requires longitudinal research, in the sense that, it is necessary to observe the outcomes throughout the years. Even decades after the ruling, sometimes it is still possible to verify some specific aspects of social reactions, drawing upon the same rationale of the radioactive effects of a nuclear disaster (e. g. Chornobyl). For instance, last year, in August, the Constitutional Court of Ukraine held to declare the decree of the President "On Appointment of Artem Sytnyk as the Director of the National Anti-Corruption Bureau of Ukraine" unconstitutional. The side effects of the ruling are still being perceived nowadays (No. 9-r/2020). This energy is transferred for the next event, that is, the decision on October 27 about the powers of the National Agency for the Corruption Prevention (No. 13-r/202O). Similarly, the ruling on the unconstitutionality of the enrichment provision (No. 1-r/2019) is alive in social conscience, reinforcing the stereotype of the court as an obstacle to the Euromaidan achievements. The interaction between decisions produces a chain reaction, where each backlash is cumulated to the next one.

Then, the status of backlash is not definite in a short period. This observation is especially important in Ukraine's case because the ruling analyzed was rendered at the end of 2020. To sum up, the status is not static. It can advance to a higher level over time.

The purpose is to apply this methodology to the ruling decided by the Constitutional Court of Ukraine on October 27 (No. 13-r/202O), measuring its impact, in order to compare it with other controversial rulings in the world. Why is this comparison relevant? Over time, this approach allows a data set building: By selecting a group of rulings with a similar index, rendered by courts from countries with close democratic backgrounds, it is more likely to find common aftermath and maybe inductively infer reasonable predictions. Possibly, in doing so, it would be advisable to follow the methodology of the "Principles of case selection in inference-oriented comparative studies," more specifically the logic of "the principle of the most similar cases" or "the principle of the most different case", in a systematic examination of a small number of cases ('Small-N').42 The enterprise requires data analyses and observations along the time, but the first task is to select representative cases such as the aforementioned Ukrainian Constitutional Court decision.

Therefore, regarding the questions, they are as follows:

I. Did the ruling receive explicit and persistent criticism by diversified media vehicles or by authorities in public statements? (No: 0 ; Yes: 0.5 , if weak; 1.0 if strong)

Yes, in a strong fashion (1.0). Due to the ruling issued on October 27, the press referred to the tribunal as a "scandal court." 43 After qualifies the court as a "cornerstone of corruption," Sergii Leshchenko said that the

42 Hirschl, On the blurred methodological Matrix of Comparative Constitutional Law, 6 o.

43 Anna Myroniuk, "Zelensky Convenes National Security Council over Threat to Anti-corruption Institutions", KYIV Post, October 29, 2020, accessed December 25, 2021, https://www.kyivpost. 
"Constitutional Court has to be stopped." 44

The ruling was openly criticized by many authorities, from the German Ambassador ${ }^{45}$ to the main critic: President Zelenskyy. The secretary of the country's National Defense Council, Oleksiy Danilov, classified the ruling as a threat to national security. The head of the National Agency for the Corruption Prevention (NAPC), Oleksandr Novikov, also criticized the decision. ${ }^{46}$

Even the Venice Commission, in its First Emergency Opinion(No.1012/2020), does not hesitate to pronounce that the Constitutional Court's reasoning is "flawed in many respects," "has no firm basis in international law," and "may produce critical adverse effects for the functioning of anti-corruption bodies, which is extremely worrying." The Commission also stresses "a conflict of interest of some judges," warning that the manner in which the CCU operated in this case "will affect the public perception of the institution", representing "a serious challenge for the Ukrainian legal order."

II. Was the ruling questioned in protests, strikes, marches, rallies, riots, civil unrests, demonstrations, parades, or other reactive manifestations from the civil society? (No: o; Yes: 0.5, if weak; 1.0 if strong)

Yes, in a strong form (1.0). According to the press, several hundred protesters rallied outside the court building, demanding the judges' ouster. ${ }^{47}$ Students and activists held posters with vulgar words, such as "Remove Pigs from the Constitutional Court." 48 There is no room for doubts regarding this question. Due to the protesters, the National Guard was called to attend.

III. Has the ruling been used as a springboard for electoral candidacies? Did the result of the elections immediately following the decision proclaim as winners

com/ukraine-politics/zelensky-convenes-national-security-council-over-threat-to-anticorruption-institutions.html.

44 Sergii Leshchenko, "Constitutional Court, a Cornerstone of Corruption, has to be Stopped," KYIV Post, October 23, 2020, accessed December 25, 2021, https://www.kyivpost.com/article/ opinion/op-ed/sergii-leshchenko-constitutional-court-a-cornerstone-of-corruption-has-to-bestopped.html.

Mattia Nelles, "Ukraine Caught between Constitutional Crisis and Counter-revolution," Atlantic Council, November 5, 2020, accessed December 25, 2021, https://www.atlanticcouncil.org/ blogs/ukrainealert/ukraine-caught-between-constitutional-crisis-and-counter-revolution/. “Ukraine President Slams 'Unacceptable’ Corruption Ruling,” DW(Deutsche Welle), October 29, 2020, accessed December 25, 2021, https://www.dw.com/en/ukraine-president-slams-unacceptable-corruption-ruling/a-55439279.

Yuras Karmanau, “Ukraine's President Moves to Dissolve the Top Court over a Ruling," AP News, October 30, 2020, accessed December 25, 2021, https://apnews.com/article/ukraine-media-cour ts-9cfo4937d4807589o3fao3od5cf872af. 
candidates who pledged to confront the measure, producing an electoral panorama that is different from what was traditionally observed in the last decade? Or still: Did the sudden loss of political mandates exercised by politicians — traditionally stabilized in the political career and whose performance is in favor of the controversial measure - occur? (No: 0 ; Yes: 0.5 , if weak; 1.o if strong. The first question represents a weak impact. The others, a strong result)

At the moment, it is too early to answer this question (o). Only by carefully observing the next electoral results, in a longitudinal perspective, it would be possible to assert the precise reaction in this field.

IV. Did the ruling arise legislative reactions against itself? (No: $\circ$; Yes: 0.5 , if weak; 1.0 if strong)

Yes (0.5). Few days after the ruling, 24 (twenty-four) bills were drafted in the Parliament in order to either overrule the decision, by renewing the anti-corruption structure or change the court itself. ${ }^{49}$ Legislatures submitted a bill to reinstate the asset declaration system, ${ }^{50}$ as well as Zelenskyy drafted a bill to annul the court's ruling. Two political actors, then, reacted to the ruling by using legislative measures. Although the expressive reaction, neither of these bills were adopted by the Parliament. ${ }^{11}$ For this reason, given that, at the moment, there is no an approved act, I consider the attempts as a weak reaction. As soon as one of the bills is approved, the score must be raised to 1.0.

V. Has the composition of the court changed due to the controversial decision, through strategic appointments with the objective to promote alterations in the court's approach? (No: 0 ; Yes: 0.5 , if weak; 1.0 if strong)

For the time being, it is also too early to evaluate (o). Over time, the decision will be stabilized, granting an answer to this question. Only time will tell, but, all things considered, it is very likely to occur.

VI. Were there (attempts to) impeachment of the Justices? (No: o; Yes: o.5, if weak; 1,0 if strong)

For the time being, no (o).

VII. Did the civil unrest reach the level of a significant refusal to comply with the decision, characterizing broad civil disobedience? (not applicable: Ø)

The decision under analysis was addressed to the State, not to the citizens (Ø). As this question is not applicable, it may not be considered in the arithmetic mean. Then, it will be necessary to adjust the denominator of the fraction ( 9 , instead of 10).

"Ways to Resolve Constitutional Crisis Proposed by MPS," International Ukraine, November 12, 2020, accessed December 25, 2021, https://ti-ukraine.org/en/news/ways-to-resolve-currentconstitutional-crisis-proposed-by-mps/. 
VIII. Has the decision ceased to be enforced by officials and authorities, with the deliberate intention of ignoring it? (No: o; Yes: o.5, if weak; 1.o if strong)

Somehow, yes (0.5). The decision of the court was ignored by the Ministers of Zelenskyy's Cabinet. They urged the National Agency for the Corruption Prevention to disobey the ruling, ordering the resume of assets declarations as if the decision had not existed or if it had been a ghost in the legal world.

Notwithstanding this relevant attempt to empty the ruling, the main addressees observed it. Consequently, over a hundred criminal cases investigated by National Anti-Corruption Bureau have been dropped. The NACP also complied with the ruling, refraining from investigating certain State institutions.

IX. Did the decision produce arbitrary acts of court-packing, budget cuts, or other measures of institutional attack? (No: $\circ$; Yes: 0.5 , if weak; 1.0 if strong)

Of course (1.0). This characteristic appears strongly, given that the President suspended the Chief Justice for two months without the permission of the Constitution. He also drafted a bill to fire all the judges of the court (Draft Law No. 4288).

The movements characterize institutional attacks, not a constitutional reaction. However, unlike the institutional attack of the horizontal perspective, where institutions are struggling regardless of people's will, Zelenskyy did it on behalf of the Ukrainian people - even if he eventually had also a political interest in doing so.

Furthermore, lawmakers introduced bill proposals to increase the quorum of the court, expanding its number of Justices to 17 (seventeen) ${ }^{52}$ and probably blocking its work. ${ }^{53}$ They also introduced proposals to deprive the Constitutional Court of funding.

$X$. Is it possible to verify a relationship between the decision and armed attacks or conflicts, such as civil wars? (No: $\circ$; Yes: 0.5 , if weak; 1,o if strong)

Yes, however, in a weak form (o.5). The protesters didn't only attack the ruling in thesis, but also the court building itself, by using military artifacts. According to the press, protesters threw smoke grenades into the court building and threatened to move in, while some set tires ablaze. ${ }^{54}$ The target was not an idea, but instead the tribunal. The behavior represents a concrete act of violence against the proper court as an institution, even though the integrity of the judges had been preserved. More than a simple protest, the smoke grenade throw is considered a weak form of armed conflict.

$$
(\mathrm{i})=\frac{1+1+0+0.5+0+0+0.5+1+0.5}{9}=0.5
$$

\footnotetext{
$5^{2}$ Channell-Justice, Ukraine's Constitutional Court Crisis, Explained.

53 Second Emergency Opinion. European Commission for Democracy Through the Law (Venice Commission), Opinion No. 1012/2020:4.

"Ukraine: Protests in Kyiv after Top Court Scraps Anti-graft Laws," DW(Deutsche Welle), October 30, 2020, December 25, 2021, https://www.dw.com/en/ukraine-protests-in-kyiv-after-top-court-scraps-anti-graft-laws/a-55445983.
} 


\section{Morphology of Impact on "27 October Ruling"}

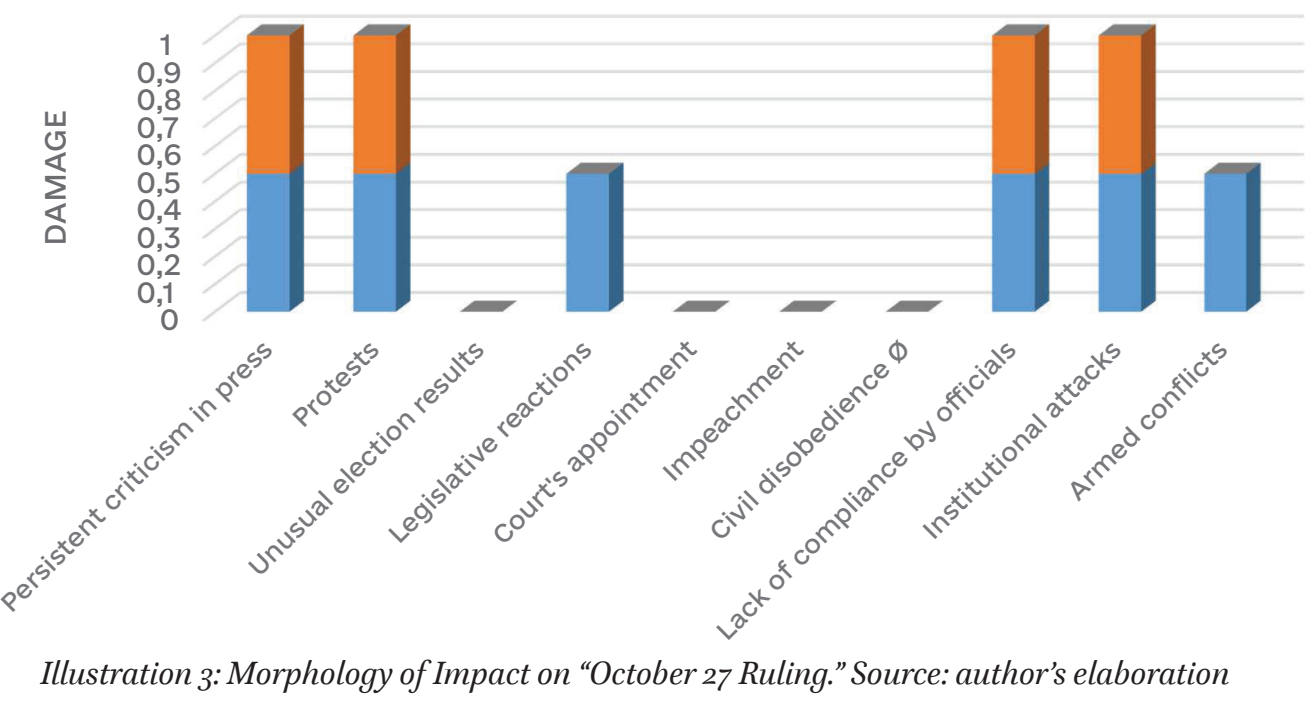

\section{Findings and Conclusion}

In such an abbreviate time, 0,5 represents an expressive index of backlash, as the probable peak of social reaction hasn't been reached yet. Comparatively, Brown v. Board of Education, in 1954, a famous decision where the Supreme Court of USA promoted the racial desegregation in schools, has the close index of $0.55 .{ }^{55}$ Roe v. Wade, in 1973, an inflame precedent universally recognized as the ruling which allowed abortion and sparked a cultural war in the United States, has an index of $0.65 \cdot{ }^{56}$

These decisions, however, were stabilized throughout the decades. The Ukrainian Constitutional Court produced such a controversial ruling that, in just one semester, on average, is almost overcoming the most famous prototypes of backlash reaction in the Comparative Constitutional Law. This result has just placed the court's decision on the list of the most impactful of the world.

Metaphorically, the impact index of 0.5 means a big wave that probably announces an imminent tsunami. Nonetheless, while a tsunami does not destroy houses made of stone, it does destroy houses built of wood. Transitional democracies, with their comorbidities, are like houses built of wood. An impact higher than o,6 requires a stable and resilient democracy, but, as some scholars have argued,

"Ukraine is stable in its political instability." ${ }^{57}$

If the gravity of the scenario described was not enough, it is worth stressing that the index presented focuses primarily on a domestic backlash. However, the Ukrainian case

\footnotetext{
55 Fonteles, Direito e Backlash, 111.

56 Fonteles, Direito e Backlash, 111.

57 Cherviatsova, Ukraine, 319.
} 
has the peculiarity of a concurrent international backlash, external coercion exercised by international actors over the decision rendered by the Constitutional Court (e.g IMF, European Union, Venice Commission, etc.). The Venice Commission, for instance, suggested reforms in the Court as a direct response to the decision studied. Therefore, when one takes into consideration international relations, the panorama is even worse.

Given the aforementioned background, it is reasonable to infer that the Ukrainian Constitutional Court has clearly crossed the line. At the same time, it went beyond the tolerance interval and triggered a fierce backlash, that is, both sources of attacks - in a horizontal and vertical perspective, respectively - were actioned by the Tribunal.

The double challenge certainly produces a synergetic effect and the risk is greater if one considers the previous existing comorbidities: The democratic index of Ukraine, the tendency of autocracy in the presidency, and the lack of public trust in the judicial system.

Definitely, the court is in a worrying position regarding its longevity. As well remembered,

"the decision was met with so much backlash that the rule of law in Ukraine is now at stake." 58

Indeed, it is.

The Hungarian literature suggests that it was precisely the activism of the Hungarian Constitutional Court that caused its deformation as an institution. As the former Justice István Stumpf points out, the Hungarian Constitutional Court has already been considered the most powerful court in the world, exerting influence over the Constitutional Courts of Lithuania, Ukraine, Albania, and South Africa. ${ }^{59}$ Acting as a powerful counterweight of the Executive branch, the Court ended up not surviving intact to the constitutional reforms. ${ }^{60}$ Today, the Hungarian Constitutional Court is deferential to the Executive and Legislative, which is corroborated by empirical data. ${ }^{61}$

Inductively, it seems that the present of the Hungarian Constitutional Court is the near future of the Ukrainian Constitutional Court. And, at this point, it is no longer worth trying to preserve the tribunal through the adoption of a constitutional adjudication marked by self-restraint. It is too late.

$5^{8}$ Nekoliak, A Damaged Court Causing a Constitutional Crisis: The Decision of Ukraine's Constitutional Court on the Anti-Corruption Reform.

István Stumpf, Reinventing Government. Constitutional Changes in Hungary (Hungary: Gondola, 2017): 57 .

6o Eszter Bodnár, Fruzsina Gárdos-orosz and Pozsár-szentmiklósy, "The State of Liberal Democracy," The I·CONnect-Clough Center 2017 Global Review of Constitutional Law (August 2017): 13, accessed December 25, 2021, https://www.academia.edu/37150485/Hungary_ The_State_of_Liberal_Democracy.

61 Eszter, Gárdos-orosz and Pozsár-szentmiklósy, The State of Liberal Democracy, 13 o. 


\section{Bibliography}

Alina Cherviatsova, "Ukraine", The I.CONnect-Clough Center 2018 Global Review of Constitutional Law (October 2018): 319-324. Accessed December 25, 2021. https:// papers.ssrn.com/sol3/papers.cfm?abstract_id=3471638.

Bodnár Eszter, Fruzsina Gárdos-orosz and Zoltán Pozsár-szentmiklósy. 2018. "The State of Liberal Democracy," The I.CONnect-Clough Center 2017 Global Review of Constitutional Law (August 2017). Accessed December 25, 2021. https://www. academia.edu/37150485/Hungary_The_State_of_Liberal_Democracy.

Channell-Justice, Emily. “Ukraine's Constitutional Court Crisis, Explained," Ukrainian Research Institute of Harvard University, 2020. Accessed December 25, 2021. https://huri.harvard.edu/ukraine-constitutional-court-crisis-explained

Cherviatsova, Alina. "False Dilemma. The President of Ukraine vs The Constitutional Court." VerfBlog, 2021/o1/21. https://verfassungsblog.de/false-dilemma/.

Choudhry, Sujit, Sedelius, Thomas and Kyrychenko, Julia. Semi-presidentialism and Inclusive Governance in Ukraine. Reflections for Constitutional Reform. Stockholm: International Institute for Democracy and Electoral Assistance, 2018

Deutsche Welle. "Ukraine President Slams ‘Unacceptable' Corruption Ruling,” DW (Deutsche Welle), October 29, 2020. Accessed December 25, 2021. https:// www.dw.com/en/ukraine-president-slams-unacceptable-corruption-ruling/a-55439279.

Deutsche Welle. "Ukraine: Protests in Kyiv after Top Court Scraps Anti-graft Laws," DW (Deutsche Welle), October 30, 2020. Accessed December 25, 2021. https:// www.dw.com/en/ukraine-protests-in-kyiv-after-top-court-scraps-anti-graftlaws/a-55445983.

Durkheim, Émile. As Regras do Método Sociológico. São Paulo: Edipro, 2012.

Epstein, Lee, Knight, Jack and Shvetsova, Olga. 2001. "The Role of Constitutional Courts in The Establishment and Maintenance of Democratic Systems of Government." Law and Society Review 35, no. 1 (2001): 117-164. https://doi.org/10.2307/3185388

Fonteles, Samuel S. Direito e Backlash. Salvador: Juspodivm, 2018.

García-Sayán, Diego. "Guatemala: Attacks against Constitutional Court and delays in the appointment of judges to high courts must stop, United Nations Human Rights Officer of the High Commissioner, November 19, 2020. Accessed December 25, 2021. https://www.ohchr.org/en/NewsEvents/Pages/DisplayNews.aspx? NewsID=26521\&LangID=E.

Ginsburg, Tom and Versteeg, Mila. "Binding the Unbound Executive: Checks and balances in time of pandemic." Public Law and Legal Theory Research Paper Series. Virginia: University of Virginia School of Law, 2020.

Hirschl, Ran. "On the Blurred Methodological Matrix of Comparative Constitutional Law", The Migration of Constitutional Ideas, ed. by Sujit Choudhry (Cambridge: Cambridge University Press, 2007).

International Ukraine. "Ways to Resolve Constitutional Crisis Proposed by MPS," International Ukraine, November 12, 2020. Accessed December 25, 2021. https:// 
ti-ukraine.org/en/news/ways-to-resolve-current-constitutional-crisis-proposedby-mps/.

Karmanau, Yuras. “Ukraine's President Moves to Dissolve the Top Court Over a Ruling," AP News, October 30, 2020. Accessed December 25, 2021. https://apnews.com/ article/ukraine-media-courts-9cfo4937d4807589o3fao3od 5 cf872af.

Klarman, Michael. "Courts, Social Change and Political Backlash" (Speaker's notes, Washington, DC, March 31, 2011), Georgetown University. Accessed December 25, 2021. https://scholarship.law.georgetown.edu/cgi/viewcontent. cgi?article $=1001 \&$ context $=$ hartlecture.

Kurland, Philip B. "Toward a P. Supreme Court”, University of Chicago Law Review 37, no. 1 (Fall 1969): 2o. https://chicagounbound.uchicago.edu/uclrev/vol29/iss4/16

Leshchenko, Sergii. "Constitutional Court, a Cornerstone of Corruption, has to be Stopped," KYIV Post, October 23, 2020. Accessed December 25, 2021. https://www. kyivpost.com/article/opinion/op-ed/sergii-leshchenko-constitutional-court-acornerstone-of-corruption-has-to-be-stopped.html.

Levitsky, Steven and Ziblatt, Daniel. How Democracies Die. What History Reveals About Our Future. Harlow: Penguin Book, 2018.

Marusiak, Oleksandr. "Ukraine", The I·CONnect-Clough Center 2020 Global Review of Constitutional Law (March 2021): 320-323. Accessed December 25, 2021. https:// papers.ssrn.com/sol3/papers.cfm?abstract_id=3800451.

Monaghan. Henry P. "Constitutional Adjudication: The Who and When." Yale Law Journal, 82, no. 7 (June 1973): 1363-1397. https://www.jstor.org/stable/i232566.

Myroniuk, Anna. "Zelensky convenes National Security Council over Threat to Anticorruption Institutions," KYIV Post, October 29, 202O. Accessed December 25, 2021. https://www.kyivpost.com/ukraine-politics/zelensky-convenes-national-securitycouncil-over-threat-to-anti-corruption-institutions.html.

Nekoliak, Andrii. "A Damaged Court Causing a Constitutional Crisis: The Decision of Ukraine's Constitutional Court on the Anti-Corruption Reform." VerfBlog, 2020/12/05. Accessed December 25, 2021. https://verfassungsblog.de/a-damaged-court-causing-aconstitutional-crisis/.

Nelles, Mattia. "Ukraine Caught between Constitutional Crisis and Counter-revolution," Atlantic Council, November 5, 2020. Accessed December 25, 2021. https://www. atlanticcouncil.org/blogs/ukrainealert/ukraine-caught-between-constitutionalcrisis-and-counter-revolution/.

Posner, Richard A. "Against Constitutional Theory." New York University Law Review 73, no. 1 (April 1998). https://chicagounbound.uchicago.edu/journal_articles/1855/.

Razumkov Centre. "The Beginning of a New Political Year: Trust in Social Institutions," Razumkov Centre, July 202O. Accessed December 25, 2021. https://razumkov.org. ua/napriamky/sotsiologichni-doslidzhennia/pochatok-novogo-politychnogoroku-dovira-do-sotsialnykh-instytutiv-lypen-2020r. 
Reuters. "Ukraine Leader Asks MPs to Annul Court Ruling on Anti-corruption Laws," Reuters, October 30, 202O. Accessed December 25, 2021. https://www.reuters.com/ article/uk-ukraine-court-law-idUKKBN27FoXO.

Rosenberg, Gerald N. The Hollow Hope. Can Courts Bring About Social Change? Chicago: The University of Chicago Press, 2008.

Second Emergency Opinion. European Commission for Democracy Through the Law (Venice Commission), Opinion No. 1012/2020:4.

Sorokin, Oleksiy. "Constitutional Court Judges Live Far Beyond their Stated Means," KYIV Post, November 6, 2020. Accessed December 25, 2021. https://www.kyivpost. com/ukraine-politics/constitutional-court-judges-live-far-beyond-their-stated-means.html.

Stumpf, István. Reinventing Government. Constitutional Changes in Hungary. Hungary: Gondola, 2017

Sunstein, Cass R. "Backlash's Travels." In University of Chicago Public Law \& Legal Theory 157 (2007). https://chicagounbound.uchicago.edu/public_law_and_legal_ theory/38/.

Transparency International. “Corruption Perception Index,” Transparency International, 202O. Accessed December 25, 2021. https://www.transparency.org/en/countries/ ukraine.

Tsebelis, George. Veto Players. How Political Institutions Work. New Jersey: Princeton University Press, 2002.

Tushnet, Mark. Advanced Introduction to Comparative Constitutional Law. Northampton: Edward Elgar, 2014.

Yesmukhanova, Yulia. "Score Changes in 2020," Freedom House, 2020. Accessed December 25, 2021. https://freedomhouse.org/country/ukraine/nations-transit/2O2O.

Zveriev, Ievgen. "Interpretation Theories in Ukrainian Courts—Past and Present," Acta Juridica Hungarica 56, no. 1 (March 2015). https://law.ukma.edu.ua/interpretation-theories-in-ukrainian-courts-past-and-present/.

Samuel Fonteles is a prosecutor, former public defender, writer and speaker in Brazil. Currently, he works as an assistant of the Prosecutor General before the Brazilian Supreme Court, having been accepted as a visiting scholar at Stanford Law School (USA - 2022). He is a PhD candidate at Federal University of Paraná (UFPR Brazil) and holds a Master's Degree in Constitutional Law from Brazilian Institute of Education, Development and Research (IDP - Brazil). His research is focused on the interaction between Constitutional Courts and the people (backlash phenomenon), as well as comparatives studies in Constitutional Law and constitutional interpretation. Mr. Fonteles has an extensive academic production on Constitutional Law. In 2019, considering a proposed amendment to the Constitution, a senator mentioned one of 
his books, calling it "the most authoritative doctrine." 62 His works have been cited, among others, by the Brazilian Supreme Court. He has attended courses in Spain (Universidad de Sevilla), Italy (Università di Roma Tor Vergata), presented works in Serbia (Univerzitet u Beogradu - Fakultet političkih nauka — 2018), The United States (Barry University2019), South Korea (Sungkyunkwan University—2019), and Hungary (Széchenyi István University - Györ - 2020). Mr. Fonteles is Reviewer of many Journals, including the "International Relations and Diplomacy" (American Journal-New York). As a speaker, he led classes on TV Justiça, a TV channel that belongs to the Brazilian Supreme Court. 


\title{
Конституційний Суд України: Атаки та Реакція у Відповідь
}

\author{
Самуел Фонтелес \\ докторант \\ Федеральний університет Парана, Бразилія
}

\begin{abstract}
Анотація
Мета цієї статті-проаналізувати Конституційний суд України у світлі теорії допустимого інтервалутатези про реакціюу відповідь черезприкладнедослідження Рішення КСУ від 27 жовтня 2021 року, яким визнано неконституційними частину повноважень Національного агентства з питань запобігання корупції (НАЗК). Виділяються три “патології" - відповідні умови, які послабляють суд і роблять його вразливим до атак в Україні: українська демократія, автократичні тенденції президентської влади та відсутність довіри громадян до судової системи. За допомогою підходів порівняльного конституційного права сформоване мірило, яке визначає вплив рішення, що дозволяє здійснювати порівняння його наслідків із іншими визначними дискусійними судовими рішеннями в світі. Після опису висновків у статті подані розмірковування та прогнози щодо довговічності Конституційного суду України.
\end{abstract}

Ключові слова: реакція у відповідь, теорія допустимого інтервалу, атаки, Конституційний суд, Україна 